\title{
A Study on the Probing Solutions for the Early Childhood Character Education
}

\author{
Bo Ki Pyon1)
}

\begin{abstract}
This study is aimed at grope for a desirable direction of children's personality education. In order to accomplish the purpose of study, the importance of early childhood in personality education was identified first. And then the concept of personality education was presented, so the implication that could be applied to the children's personality education in these days was drawn through theoretical consideration of personality education. The educational theories of Montessori, Steiner and Pestalozzi have been examined, whose educational ideas are regarded to connote desirable contents for the personality education of early childhood. Regarding the methods and contents for early childhood personality education, the importance of home education that plays a key role in personality formation has been discussed, by considering Montessori method of education, in which intrinsic motivation and self-control is emphasized and sense of responsibility and autonomy is fostered, and Steiner method of education, in which consistency of inner world, behavior and trust, and lastly the true purpose of education suggested by Pestalozzi. On the basis of such discussions, a practical way that may contribute to improvement of children's personality education has been suggested
\end{abstract}

Keywords : Personality Education, Early Childhood, Home Education, Practical Personality Education

\section{Introduction}

\section{Necessity and purpose of study}

A home is the smallest society where a human being experiences life for the first time and also it is the first place for education, so home education has the biggest influence on human development and enhancement of potential[1]. Though humans are social beings, who are constantly influenced by the environments surrounding themselves, it has been admitted that they are most influenced by such environments in early childhood among the stages of human development[2]. Each family, children's educational institutions and our society have a direct influence on children. However, in the situation where they are unequal to the task, they have achieved a significant consensus as to why our educational environment has to find a right direction urgently.

Received(November 29, 2017), Review Result(1st: December 18, 2017, 2nd: January 5, 2018), Accepted(January 12, 2018)

1) (Professor) Dept. of Social Welfare, Mokwon Univ., 88 Doan-dong Seo - gu , Daejon, Korea email: bkpyon@hanmail.net 
A lot of people have a sense of social crisis, and in the end of such contentious discussions, educational problems are raised at all times. And it is emphasized that education is one of the important solutions which may help us escape all the crises, and especially the solution should be more focused on personality education among all the education in parallel with social policy-based solutions. There is no question that practice-based personality education shall be provided from childhood. John Dewey argued that most profound moral education was to encourage humans to have a proper relationship with others[3]. And Archambault (1964) stressed the importance of personality education, saying it was difficult or impossible for the educational system to provide pure and normal moral education as long as it was destroying or ignoring such harmonies[3]. It implies that the purpose of personality education in childhood can be achieved by developing the ability to recognize and understand each other in contact and relationship with others, so the purpose of personality education cannot be achieved when the system concentrates only on intellectual education or specialty-oriented education. Furthermore, Lickona warned by saying, "Educating a person to become an intellectual without morality does not differ from bringing a dangerous man into society[4]. Wether it is required to recall the educational ideas of Pestalozzi who put great importance on heart, though putting stress on harmony among head, heart and hand, we cannot help but emphasize the importance of personality education. And also, we have to fundamentally reconsider our education, which is in the frenzy of early education, in consideration of the fact that a person nurtured only by knowledge-oriented education may do real harm to the society by using the knowledge.

This study is aimed at groping for a desirable direction of personality education after defining the problems in each field, which is followed by reviewing the importance of early childhood in personality education, home education and personality education itself.

\section{Contents}

\subsection{Importance of early childhood in personality education}

As the great thinkers had begun to get a new understanding of the human nature, education and nurture at the time of Reformation and Renaissance in the 16th century, children began to be recognized as an independent human, not a miniature of adult, by John Locke's Tabula Rasa and Rousseau's Phased Development Theory[5]. Especially, his profound respect for children provided a philosophical basis for the development of children's education. And also, his child-centered educational idea suggested an epoch-making and new view of child. To use his words, natural 
goodness is inherent to children who are God's creatures, so that education must be provided in a way that makes them express their natural selves. In other words, education can be interpreted as positive actions to preserve the innate good human nature. A number of educational thinkers, who came after Rousseau, have emphasized on providing child education based on the unique characteristics, development and desires of children.

R. A. Spitz reported that a child's character was formed in a 'Closed system' during the first year after birth[1]. And it is agreed that the basis of intellectual development is formed at early childhood. Piaget argued that the sensory-motor intelligence at the period became a basis for the representative thinking that came later. In other words, the representative thinking could develop properly only if a child could have enough sensory and motor experience in the sensorimotor stage (0-2years old). This implies that because of the phased development, the childhood education in which children's early experience is acquired becomes a basis of human development.

Accordingly, if the development that shall be achieved at the childhood has not been achieved properly, it would be difficult to recover later due to damage accumulation. So, the education shall be provided on time. In short, the timeliness of development means that there is an optimal period, that is to say, a critical period for achievement of specific tasks in every aspect of development[2].

Erikson, who insisted on the Theory of Psychosocial Development, which was focused on human relationship, including social factors and peer relationship, introduced 8 stages human development process from birth to old age, explaining the basic tasks symmetrically, which should be acquired at each stage. According to Erikson, the period of 0 18 months is the best time for formation of trust, the period from 18 months to 3 years is the best time for autonomy, and the period of $3 \sim 6$ years is the critical time of formation of the initiative. He also emphasized that both poles should be balanced in order to transit into next stage because the damaged development, which was not achieved in the proper time, could not be recovered[2].

\subsection{Concept of personality education}

It is difficult to define the terminology 'personality' in a single word because it has abstract and comprehensive meaning. Locke regarded personality as an ability to suppress desire and feeling and follow the dictates of reason. And Aristotle argued that personality was something that enabled a person to behave properly in relationships with others, as well as living a good life alone[3]. And also, Lickona(1991) defined personality as something that enabled a person to perceive goodness in terms of morality, pursuing and it and doing good[4]. Woo Yeong-hyo(2004) regarded personality as a human dignity that enabled a person to feel shame and gratitude[5]. 
By the way, if we accept personality education in a comprehensive view in which it is aimed at seeking positive value and putting it into practice for the society, the definition of personality education vary according to the changes in society and culture[6]. In the ancient times, when the education was regarded as the privilege of ruling class, Plato defined the purpose of education as cultivation of leaders. However, we may notice the change in the concept as we see that the purpose of modern education is to foster citizen consciousness, along with the changes in time[7].

In this study, the personality education is interpreted as a continuous and consistent behavior pattern that features a person, which is achieved by the education that cultivates humanity and builds character.

\subsection{Theoretical review on personality education}

\subsubsection{Personality education connoted in Montessori education theory}

Montessori defined human as a being that feared God, developed in the nature freely, and had an innate power for creative development[8]. The view of child that comes from such vie of humans leads to the respect for children. The characteristics of personality, which was defined in Montessori's view of child, can be classified under two categories. The first is a child defined as a good being in terms of morality, and the second is a child defined as true nature in terms of society and religion.

She has a belief that children are a good being in terms of morality. She says children represent the existence of potential, who possess a 'Perfect model of normality' and the energy that enable them to endlessly. Accordingly, in order to secure the formation of personality, they should free themselves from suppression and confinement imposed by adults, so that they may form their own personality in accordance with their unique vitality and development[7].

However, Montessori also emphasizes that children need to be provided with correct education for formation of personality of new human being in order to create a new society based on love, justice and harmony, because the real world depends only on superficial mechanism without moral basis. And at the same time, the overall path of civilization shall be changed by replacing the old system, in which everything is judged by standard established by adults, with a new system in which everything is judged by the standard established for children and their own sense of value. After all, Montessori argues that the goodness would be achieved by admitting the freedom of children and removing the obstacles that cause destruction and disobedience. In a sense, the social activities in Montessori education is criticized, because children are regarded as social and religious entities. However, Montessori has never neglected the social relationship and activities. She believes that 
there is a complementary relationship between individual person and society, so that individuals can make contact with communities through meeting others autonomously in an environment where freedom is guaranteed, and self realization also can be achieved through social experiences in the society[8].

The purpose of personality education suggested by Montessori is 'Normalization'[9]. In her point of view, education is a natural process implemented autonomously by individuals, and also education is achieved by experiencing environments, so it must be aimed at delivering knowledge, forming personality, and teaching social harmonies and freedom[10]. In addition, education shall be provided from the moment of birth, and it must be aimed at formation of personality for a spiritual being by obtaining the value as a member of social community on the basis of free activities. For this reason, she encouraged children to form social relationship freely by restricting their behaviors only when they infringe on rights of other children. And also, by forming mixed-age classes, she encouraged children to live a genuine social life through learning a cooperation rather than competition, and furthermore, she allowed children to form a personality as a social being. In short, obedient children who keep order and regulation, trusting themselves, would get freedom through true obedience and enjoy the freedom through the harmony with others.

\subsubsection{Personality education connoted in Waldorf education theory}

Waldorf Education established by Steiner is aimed at cultivating universal ability and basic personality that will be required for a future life. In a word, he argued that education should be aimed at pursuing a harmonious human life and becoming a 'human being' itself rather than intellectual education, through overall understanding of humans[11]. According to Steiner, the purpose of education is to help children to pave the way in their life actively by growing the inner power. The Waldorf school, which was established with claiming to be perfectly free from outside intervention and pressure, provides education in accordance only with growth and development of children and personal character and talent.

Steiner emphasized human education saying[6], "A school system must be based on perfectly free spiritual life of humans. It is required to ask what talent a person has and what can be developed from the talent, rather than asking what the person should know about the existing social order and what the person can do. When this system has been settled down, new power that comes from growing generation can be supplied to the society."[11]

Accordingly, Steiner Education aims for the education in which intention, thinking and feeling of humans are harmonized, and also the purpose of Waldorf Education is to 'realize the true human 
education'[6]. When the purposes are suggested after subdivision, we may know he aims for a well-rounded education that enables children to reach self-realization and lead an affluent life through inner freedom, along with pursuing a human education that is established on the basis of healthy life.

In order to achieve such purposes, the basic principles of Waldorf Education are established as follows. Firstly, it is required to allow children to act in keeping with their own habits, feeling sense of stability in their own surroundings, by creating spatial environments in an orderly manner. Secondly, it is required to provide children with sense of stability through specific stream of time by complying with temporal order. That is because the repeated daily life in the same rhythm, like breathing in an out, makes children have a comfortable life. Thirdly, exemplary conducts and imitation can be used. Showing exemplary conducts does not refer to a vertical relationship between an adult and child, but means an inner bonding relationship. And children's imitation ability can be developed, recognizing what they want to imitate and looking at the people surrounding them. Accordingly, the children's ability to imitate is a free expression that comes out of their inner world. Observing adults whose thinking is the same as the belief, and the thinking and actions correspond with each other, children can realize an agreement of both poles, so-called thing and intention.

\subsubsection{Personality education connoted in theory Pestalozzi education}

To Pestalozzi, 'a Home was a small Heaven'. He argued that a home was a educational venue where the basis of human formation was built, so that it could play the most important role in forming a desirable human character[12]. According to the requirements suggested by Pestalozzi, order should be maintained at home, so that a home could become a place for moral education which cultivated pure mind. The order maintained at home was a comprehensive concept that included moral order, order in life, and order in mind and spirit. Love, trust and obedience, which occurred between parents and children at the beginning, will reach a religious level. Children should be trained to get those things naturally and autonomously at home. And it should not be done through learning by rote, but children had to learn how to love, trust and obey by themselves. It was emphasized that all education should be implemented through observing the objects in life environment by using intuition[12]. Regarding the moral function of home, the role of home for moral education was emphasized because all the buds of morality could sprout if a child was brought up in a family with love and trust.

As for the purpose of home education, Pestalozzi emphasized a harmonious development of innate talents and cultivating perfect members of society. Because talent, inclination, and achievement of 
desired end varied among each individual, he argued that every child should be provided with opportunities for development of his/her ability, which should be implemented through harmonious combination of the abilities of heart, mind and hands. He also emphasized the importance of parents' role in the achievement of purpose because children would autonomously pursue goodness through the influence of parents' warm love. He also argued that morality played an important role in becoming a competent hand for society, and naturally the morality could develop in parents' love and trust, which led to the importance of family atmosphere for achievement of educational purpose. As for a means of education, Pestalozzi put emphasis on adult's role in helping children with autonomous activities. He emphasized that respecting spontaneity was equal to respecting life. He recognized that spontaneity was the driving force of education, and true education could be implemented when a mother encourage her child to listen to the voice coming out of inner world, and to tell right from wrong[12].

He also argued that adults should not take forfeit of opportunities with which children could use their sense and abilities. And he put emphasis on the fact that children should become a main agent of intellectual education, so that the education could encourage them to achieve a standard for habit, pattern of behavior and value judgement through direct experience. Under the premise that kindness is maternal affection and kindness should be accepted as a principle for character formation and education, Pestalozzi argued that there should be kindness and encouragement in children's education consistently, however, a true education could be implemented with self-controlled love by refusing unreasonable demands[13].

\section{Conclusion}

As for the personal characteristics in the Montessori education, we may focus on the fact that the method is world-oriented and based on the respect for personality, and it puts emphasis on internal motive and self-discipline to derive autonomous action by promoting children's interests. Especially, as for the personality-related educational effects that may obtained from daily practices, we may focus on the fact that children may have delight and pleasure that can be felt through practice and they also may form desirable social relationship with others. And also the effects include fact that children may improve their sense of responsibility and spirit of independence with which they can take care of the surroundings. The daily practice enables them to be rich in emotion, keep regulations and order, and develop reflective thinking to correct their errors.

The most important goals of personality education suggest by Waldorf are Verbindlichkeit and Moral, which come out of inner world. Looking into our reality where inconsistency between thought 
and action, or thought and trust, is accepted as universal, we have to reconsider seriously the direction of desirable personality education. We need to reconsider if we are crating humans with dual nature under the cloak of purpose to cultivate adaptability.

The personality education at early childhood shall be implemented through 'partnerschaftliche Begegnung' which was emphasized in Waldorf Education. We have to show our own bright sides through meeting, and when adults can educate themselves to the same level as children, the true children's education will be realized.

According to Pestalozzi, a mother is a best teacher, a home is the best place for education, and education shall be focused on heart, rather than mind. He also argued that through conversation and interaction, parents take care of the important part of education that could not be achieved at school. So, he concluded that home education played a key role in well-rounded development of human beings, rather than supplementing school education. A home is a divine place where the basis of human formation is built, and it is the first social group where the educational basis is formed, especially for moral education[14].

Because the personality education is focused on acquiring standards of behavior required for various social activities, it is important to put it into practice and experience it repeatedly. Accordingly, we may say that the personality education has been achieved only when children imitate the virtue of adults in daily life and they put it into practice and habituate it to themselves. Because the personality education at early childhood is carried out as the basis, on which they grow up to be a good citizen, is built, all the adults including parents have to become a role model at home and children's educational institution. The best teaching method in personality education is to show a pattern of moral life to children directly.

The purpose of this study is to probe the ideal direrction of modern early childhood character education. To achieve the goal, this study was focused on finding out the implications, which can be obtained through the historical research of character education, to apply to the modern early childhood character education after reviewing the importance of the character education at the early childhood and suggesting the concept of character education.

The through examination of educational theories was performed on the theories of the famous thinkers, such as Montessori, Steiner and Pestalozzi, to refer to educational ideas that connote the desirable contents for the character education of early childhood. In conclusion, the methodology and the contents that are applicable to the modern early childhood character are as follows; first, the education of Montessori in which she thought much of the intrinsic motivation and the self-control, so that the self-responsibility and the self-autonomy may be fostered. Second, the education of Steiner in which he thought much of the unity of belief and behavior and the mutual meeting. Third, The 
importance of home education which is carrying out the core roles of the character education under the consideration of the real goals of education that was emphasized by Pestalozzi.

\section{Acknowledgement}

This study was funded by sabbatical program of Mokwon University, 2012.

\section{References}

[1] J. E. Kim, Developmental Psychology of Child, Chang Ji Sa, (1997)

[2] E. H. Erikson, Childhood and Society, New York: Norton Prince, (1950)

[3] P. D. Archambault, Philosophical Analysis and Education, London: RKP, (1964)

[4] T. Lickona, Education for character : How our Schools can teach respect and reponsibility, NY: Bantam Books, (1991)

[5] Y. H. Woo, A study on the educational thought of J. J. Rousseau, Journal of Child Education, (2003), Vol.12, No.1, pp.67-76.

[6] Y. K. Sung, Walfdorf Schoold and human education, Journal of Padagogy, The association of Korean Padogogy, (2000), Vol.38, No.1, pp.59-75.

[7] Y. H. Woo, Character of development in early childhood, Journal of Child Education, (2004), Vol.13, No.1, pp.147-158.

[8] M. Montessori, The secret of childhood, New York: Ballantine Books, (1966)

[9] M. Montessori, Education and peace, Child Development, (1972), Vol.62, pp.264-283.

[10] P. P. Lillard, Montessori a modern approach, S. H. Cho(trans.). Hakmoon Sa, (1995)

[11] http://www.waldorf.or.kr, November 29 (2017)

[12] J. H. Kim, Educational thought of Pestalozzi, Kyobo Books, (2007)

[13] K. H. Lee, The education of traditional culture in the early childhood curriculum, Journal of Child Education, (2002), Vol.11, No.1, pp.79-92.

[14] B. S. Bloom, Stability and change in human characteristics, New York: John Wiley and Sons, (1964) 